\title{
ANTIQUITY
}

millennium B.c., and onwards, alongside Greece and Rome, to the brightening dark of its medieval morning. What remains to be seen is whether anyone will take it. But we shall be ready for those that will; and indeed we have not lacked time for preparation. The need for something of this kind in Oxford began first to be pointed out (as Dr Joan Evans has reminded me) by Arthur Evans in I 888 - just seventy years ago. Yet the tortoise, in the end, did win the race; and we shall try.

$$
\text { C. F. C. HaWkES }
$$

\section{THE SOCIETY FOR MEDIEVAL ARCHAEOLOGY}

In the summer of 1957 , at a meeting held at Burlington House under the chairmanship of Sir Mortimer Wheeler, a new national archaeological society was founded. This, the Society for Medieval Archaeology, exists to further the study of Britain's post-Roman history by encouraging research into the surviving material evidence. The Society's activities will encompass the archaeology of the Anglo-Saxon period in Britain, in all its aspects. The period after the Norman conquest will be treated within more strictly archaeological terms of reference, so that attention will be focussed on fieldwork and excavated material rather than on those studies of art and architecture to which other societies and journals are already devoted.

The Society was founded in the belief that a centralized medium of publication would stimulate and unify contributions from the various disciplines involved. Thus, its chief purpose is to publish a journal in which the problems and results of archaeological, historical, numismatic and linguistic studies of the medieval period in Britain will for the first time be stated and discussed together. The archaeology of the European mainland will be treated in so far as it bears on the British problems and material. In short, this publication, which is to be called the Fournal of Medieval Archaeology, is intended to be truly national in scope and international in significance.

The Society will arrange an annual week-end conference. The first of the series was held in March $195^{8}$ at Sheffield, its subject being the relationship of history and archaeology in the study of the Middle Ages.

There will be an annual general meeting in London. In December 1957 a paper entitled Some Comments on the Miniatures and Ornaments of the Lindisfarne Gospels was read to the first of these meetings, by the President, Mr R. L. S. Bruce-Mitford, Keeper of British and Medieval Antiquities in the British Museum.

The other officers of the Society are : Secretary, Mr D. M. Wilson, of the Department of British and Medieval Antiquities in the British Museum; Editor, Dr D. B. Harden, Director of the London Museum; Treasurer, Mr J. G. Hurst of the Inspectorate of Ancient Monuments of the Ministry of Works. Sir Cyril Fox, Sir Thomas Kendrick, Sir Frank Stenton and Sir Mortimer Wheeler are Honorary Vice-Presidents.

Membership is open to all who are interested. The subscription to the Society, including the fournal, for ordinary and institutional members is $£_{2} 2 s$. od.; for bona fide students under the age of twenty-five $f_{\mathrm{I}} \mathrm{I} s$. od.; and for two members of the same household $f_{3} 3$ s. od. (entitling them to full privileges of membership and one copy of the fournal jointly). Further particulars can be obtained from the Secretary, at the British Museum, W.C.I.

\section{ARCHAEOLOGY IN WALES}

There is good news for those who practise archaeology in Wales or who want to know about the ancient history of western Britain. At long last, the University of Wales has established a Professorship of Archaeology, and we welcome Mr R. J. C. Atkinson, at 